\title{
FACTORS CREATING SOCIAL AMBIVALENCE AMONG PEOPLE IN PAKISTAN IN CONTEXT OF CPEC
}

\author{
Muhammad Anas Khan \\ Ph.D Scholar \\ Department of International Relations \\ FUUAST, Karachi-Pakistan \\ anasswathi@gmail.com \\ Dr. Hafiz Hammaduddin \\ Ph.D from \\ Department of International Relations \\ FUUAST, Karachi-Pakistan \\ hafizhammaduddin@gmail.com
}

\begin{abstract}
The CPEC project and its outcomes are viewed differently across Pakistan with the different genders and nature of stakeholders. Present study was devised to critically analyze the factors creating social ambivalence among people in Pakistan in context of CPEC in Pakistan along with current challenges and future perspectives. Therefore, all the respondents were the nationals of Pakistan. Results depicted that poor transparency in the program under CPEC has turned people against the projects. Additionally, people in the surrounding of the CPEC route exhibited fear pertaining to the migration of people to and far. People argued this may create chaos in the area and local people may be victimized to be ignored. Following the same footsteps, it was also observed that people have doubt in their minds that jobs are actually being created for the Chinese people. Therefore, it can be concluded that due to various factors, Pakistani community has become victim of social ambivalence and therefore, people need more guidance about the CPEC and to earn local support state should play its role and familiarize positive impacts of CPEC on the common man in the country.
\end{abstract}

Key Words: Social Ambivalence, CPEC, Project, Pakistan 


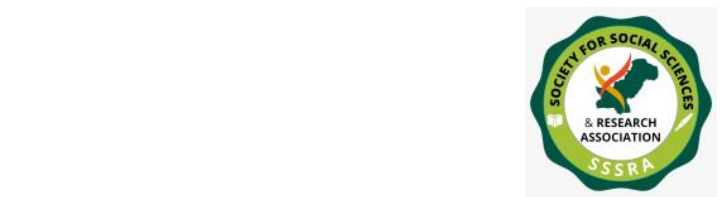

Pak. Journal of Int'L Affairs, Vol 4, Issue 2 (2021)

Factors Creating Social Ambivalence ...

\section{Introduction}

China-Pakistan Economic Corridor is a megaproject signed between Pakistan and China. Ishaque et al., (2018) had anticipated that CPEC within the OBOR project is likely to escalate the cooperative readiness including regional connectivity, infrastructure for the telecommunication, tourism, industrial parks, energy projects, agricultural growth, industrial hubs, and improvement in the health sector and improving people to people networking in the region (Alam, 2019; Basit et al., 2019; Fayyaz, 2019; Khan, 2019b; Korolev, 2019; Larson, 2019; Mahesar, 2019; Mukhtar, 2019; Raza, M.A. and Mustufa, 2019; Roy, M.I. and Khalid, 2019; Shah, 2019; Shah et al., 2019; Ahmed, 2020; Fasola, N. and Lucarelli, 2020; Moniruddin, 2020; Samay, 2020). Miller (2017) had concluded that CPEC likely to equal the direct foreign investment made in Pakistan from 1970 to current. This project could bring an institutional shift in Pakistan and hefty opportunity for Foreign Direct Investment and sustainable growth (Tehsin et al., 2017; Kousar et al., 2018). This project is further anticipated to produce new avenues to enlarge the economic situation of Pakistan and the opportunity to strengthen the economy of China.

The CPEC project and its outcomes are viewed differently across Pakistan with the different genders and nature of stakeholders (Ali and Qazi, 2018). According to the report of PIPS, (2016) people were frightened of a job loss due to CPEC and some were worried about changes in the demography of the area due to CPEC implementation. People criticized the scanty engagement of local people in the planning and development of projects (Hanif, 2013; Khan, 2018; Ahmed et al., 2019; Almamatovna, 2019; Kaushiki, 2019; Khan, S.A. and Khan, 2019a; Khan, 2019; Khetran, 2019; Gupta, 2019; Sultana et al., 2019; Khan, 2020; Mankoff, J. and Kortunov, 2020; Shahid and Kralli, 2020; Soherwordi, H.S. and Munshi, 2020). Despite more engagement and involvement of local people would have resulted better (Beg et al., 2018). People asked for the transparency in the projects and job assurance to the people that the implementation of CPEC will not make them jobless. The poor transparency in the program under CPEC can turn people against the projects (Hussain, 2017).

People in the surrounding of the CPEC route exhibited fear pertaining to the migration of people to and far. People argued this may create chaos in the area and local people may be victimized to be ignored (Jaleel and Bibi, 2018). Hussain, (2017) argued that most of the viewed CPEC positively but some had skepticism as well. For instance, people had doubt in their minds that jobs are actually being created for the Chinese people. The doubt of people can impact the local industry of Pakistan and the business circle in the country otherwise (Dvorking, 2019; Naqvi and Masood, 2017; Hilali, 2019; Miro et al., 2019; Mustafa, G. and Hussain, 2019; Nadkarni, 2019; Nagra et al., 2019; Pattanaik, 


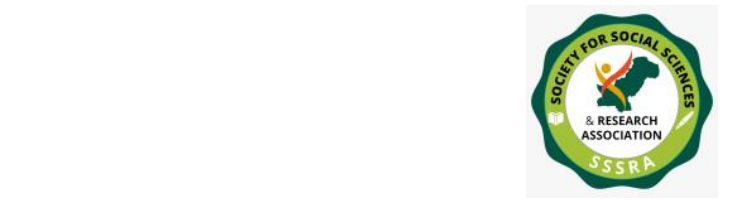

Pak. Journal of Int'L Affairs, Vol 4, Issue 2 (2021)

Factors Creating Social Ambivalence ...

2019; Rajaye, 2019; Sultana, 2019; Ibañez, 2020; Yuyan, 2020). Therefore, present study was devised with the clear objective of assessment of factors creating social ambivalence among people in Pakistan in context of CPEC.

\section{Review of Literature}

The relation between China and Pakistan is admired around the world. Ali (2017) signified the relationship "durable" despite the different political system, cultural differences. However, synergistic economic interests make both countries more closely (Ali, 2017). Dumbaugh (2010) had reported that traditional geopolitical interest fortified the good relationship between Pakistan and China. Pak-China relationship is historical. Butt (2007) augmented that Buddhist pilgrims from China started visiting Gilgit and other associated areas in Pakistan all through their elongated excursions from the areas of Kapica. The mobility between these two countries was further strengthened through the Silk route (Butt, 2007).

Recent signing and implementation of the China-Pakistan Economic Corridor (CPEC) worth of 46 Billion US Dollar accelerated the everlasting relationship (Mohapatra, 2013; Pant, 2017; Alam, 2019; Basit et al., 2019; Fayyaz, 2019; Khan, 2019b; Korolev, 2019; Larson, 2019; Mahesar, 2019; Mukhtar, 2019; Raza, M.A. and Mustufa, 2019; Roy, M.I. and Khalid, 2019; Shah, 2019; Shah et al., 2019; Ahmed, 2020; Fasola, N. and Lucarelli, 2020; Moniruddin, 2020; Samay, 2020). This profound project is a mix blend of different projects related to power generation, infrastructure and research and development (Mustaf and Zafar, 2017). Apart from that, CPEC anticipates developing special industrial and special economic zones likely to extend great opportunities of empowerment, employment and development (Hussain and Sangay, 2012; Kalim et al., 2012; Rekha, 2014; Tong, 2015; Bilgin, 2016; Khalid, 2018; Ali et al., 2019; Ansar, 2019; Guo, 2019; Gupta, 2019; Ibrahimi, 2019; Khokhar, 2019; Raghavan, 2019; Rudenko, 2019; Sahai, 2019; Bajpai et al., 2020; Konwer, 2020; Roy and Dalei, 2020).

Miller (2017) had concluded that CPEC likely to equal the direct foreign investment made in Pakistan from 1970 to current. This project could bring an institutional shift in Pakistan and hefty opportunity for Foreign Direct Investment and sustainable growth (Tehsin et al., 2017; Kousar et al., 2018). This project is further anticipated to produce new avenues to enlarge the economic situation of Pakistan and the opportunity to strengthen the economy of China. Before CPEC, China was bearing a hefty amount for trade and after CPEC transport cost for 40-feet container between Kashgar and destination ports in the Middle East squeezed to 1450 US dollar while 1350 US dollar in case of destination port in Europe (Vousinas, 2014; Akram, 2016; Shah and Parveen, 


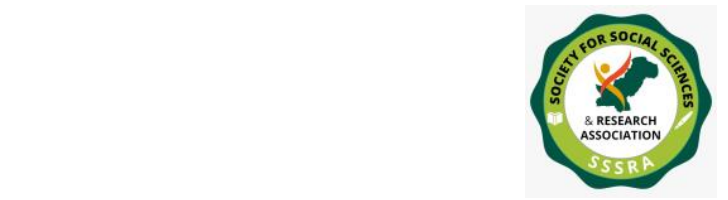

2016; Siddiqi, 2017; Mumtaz et al., 2018; Dar, 2019). Moreover, travel time duration shrinks to 21 to 24 days and 21 days for the destination port in the Middle East and Europe respectively. As for as distance is concerned, from Kashgar to Europe and the Middle East lowered to 11000-13000 Kilometres (Alam et al., 2019). CPEC will turn Pakistan a global competitor through significant influence on industrial growth and urban development (Khan et al., 2019). Moreover, Ishaque et al., (2018) found a great possibility of expansion of trade volume across the Asian region through CPEC. The effects of CPEC on Foreign Direct Investment were found highly significant by Rashid et al., (2018). The study summarized that FDI to Pakistan could help the country to encounter domestic savings, investment gaps with more improvement in business and infrastructure development (Thoker, and Singh, 2017; Zia, 2018; Biswas, S. and Chakraborty, 2019; Chaudhry, 2019; Gusevskaya, 2019; Hongdo et al., 2019; Hussain, 2019 a, b; Jerotijević, D. and Jerotijević, 2019; Khan, 2019; Lukin, 2019; Malik et al., 2019; Paszak, 2019; Sehgal, 2019; Velikaya, 2019; You, 2019; Shukla, 2020). However, still there are a lot of factors that are creating hurdles in the success of the CPEC. Thus, present study is an important aspect to consider such type of factors that are hindering in the way of CPEC success.

\section{Research Method}

\section{Framework}

This is a qualitative as well as quantitative research that has been conducted through semi-structured interviews. The focused group for this study was the residents of the Pakistan that are more closely linked with the CPEC and are living in the nearby areas. A total of 600 interviews have been conducted from common people. The questions included in the interview, have been pertinent to critically analyze the factors creating social ambivalence among people in Pakistan in context of CPEC in Pakistan along with current challenges and future perspectives. Therefore, all the respondents were the nationals of Pakistan. The case studies had been picked up from any part of the country which were the most relevant and the latest.

\section{Sampling technique}

The sampling technique has been used as simple random sampling. Data has been collected with the help of interviews and questionnaire as well as data obtained by the authentic sources. The randomization was proceeded through simple excel formula "=rand". 


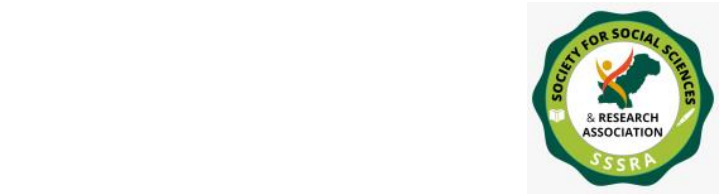

Factors Creating Social Ambivalence ...

\section{Research Design}

The planned study is the shadow of rational standpoint of the interpretative school of thought; it is espouse qualitative research technique to regulate the research inquiries. Customarily qualitative researches antedate to put the emphasis on exposure, discernment and indulgent from the viewpoint of their focus and suggests about the utmost effort for creating a clear change in the lives of common people. Merriam, (2009) has explained the qualitative research as; "Qualitative researchers are concerned in analyzing the assembled thoughts of people, along with their thought about the world and their experience while living in that world. Keeping in view the above mentioned definition of qualitative research, we can conclude that qualitative research is best suited to the present study planned to perform.

\section{Data Collection}

Data has been collected by using all the possible sources that were helpful for analyzing the basic theme of our study. For this purpose, two basic categories of data collection were used namely, primary sources and secondary sources.

\section{Primary Source}

Primary data was comprised of all the data that would be comprised of the original data related to the critically analyze the factors creating social ambivalence among people in Pakistan in context of CPEC in Pakistan along with current challenges and future perspectives. For this purpose, various sites have been accomplished to understand and compose the data related to it. Furthermore, questioners were used to investigate our theme of work.

\section{Secondary Source}

Secondary data was collected from various libraries and publications (articles, newspapers and conference proceedings) showing the clear relationship with our context. Little research is done on explaining the critically analyze the factors creating social ambivalence among people in Pakistan in context of CPEC in Pakistan along with current challenges and future perspectives. Therefore, all the note-books, articles, magazines and conference proceeding showing the basis for our study were used to properly depicting our results of study.

\section{Findings}


After the detailed analysis of the collected data, it was observed that the major concern of the CPEC is to bring socio-economic development in the two countries. CPEC was anticipated to tackle energy crisis and generating employment opportunities for people of Pakistan, increased access to health and education, escalating trade and business potential to strengthen the financial position of local people. Pertinent to fast trade and enormous potential of business the level of income and employment opportunities for the people will be rising with the time. CPEC can expedite geographical connectivity and employment opportunities and by 2021 a growth will witness a $7.21 \%$ rise. However, contrary to all this Pakistani community is passing through various social ambivalence factors that are throbbing them both mentally as well as socially.

Thus, following are the major factors that are playing hard for the social ambivalence. The CPEC project and its outcomes are viewed differently across Pakistan with the different genders and nature of stakeholders. People were frightened of a job loss due to CPEC and some were worried about changes in the demography of the area due to CPEC implementation. People criticized the scanty engagement of local people in the planning and development of projects. Despite more engagement and involvement of local people would have resulted better. People asked for the transparency in the projects and job assurance to the people that the implementation of CPEC will not make them jobless.

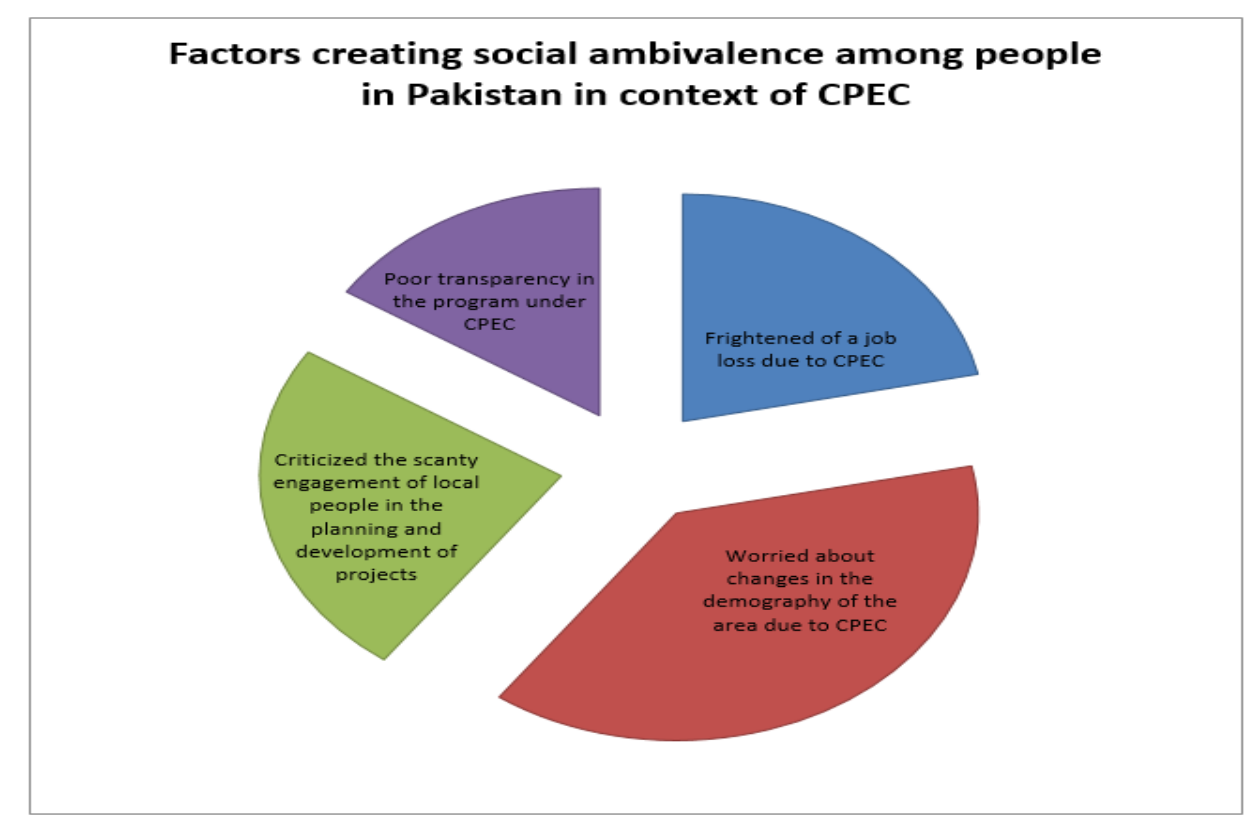

$\underline{\text { Figure \# } 1}$ 


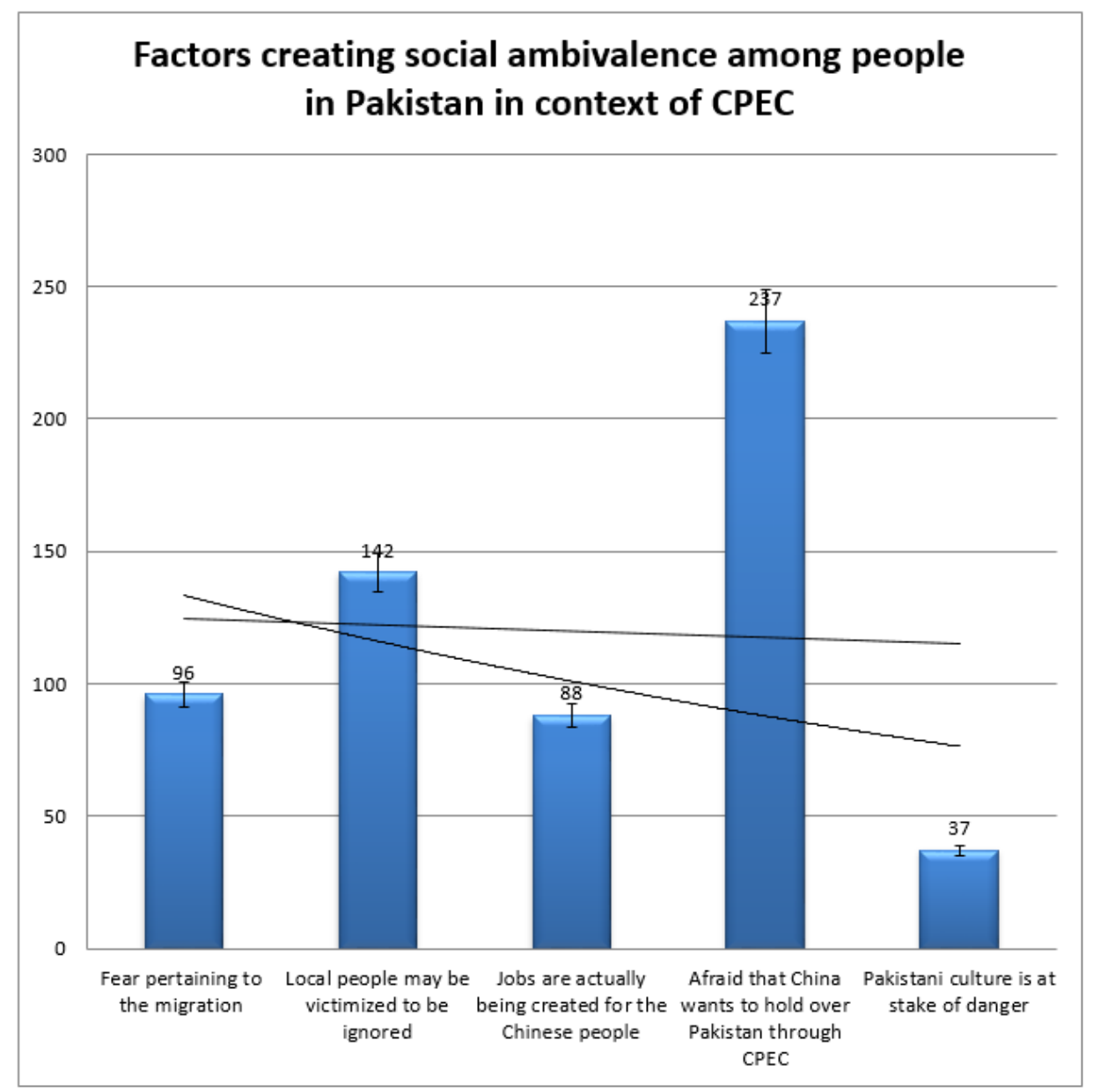

\section{$\underline{\text { Figure \# } 2}$}

Furthermore, poor transparency in the program under CPEC has turned people against the projects. Additionally, people in the surrounding of the CPEC route exhibited fear pertaining to the migration of people to and far. People argued this may create chaos in the area and local people may be victimized to be ignored. Following the same footsteps, it was also observed that people have doubt in their minds that jobs are actually being created for the Chinese people. Furthermore, Pakistani community is afraid that China wants to hold over Pakistan through CPEC. Similarly, according to the respondents 
Pakistani culture is at stake of danger due to bulk of Chinese people migration to Pakistan.

\section{Conclusion}

The doubt of people can impact the local industry of Pakistan and the business circle in the country otherwise. Therefore, it can be concluded that due to various factors, Pakistani community has become victim of social ambivalence and therefore, people need more guidance about the CPEC and to earn local support state should play its role and familiarize positive impacts of CPEC on the common man in the country. People in Pakistan often associate their own benefits with the CPEC. None of the people was found against the CPEC until their benefits are not compromised. Assurance and transparency in the projects could assist people to be a believer in CPEC projects. Though the majority of the peoples in Pakistan favor the CPEC still rooms for improvement do exist. 


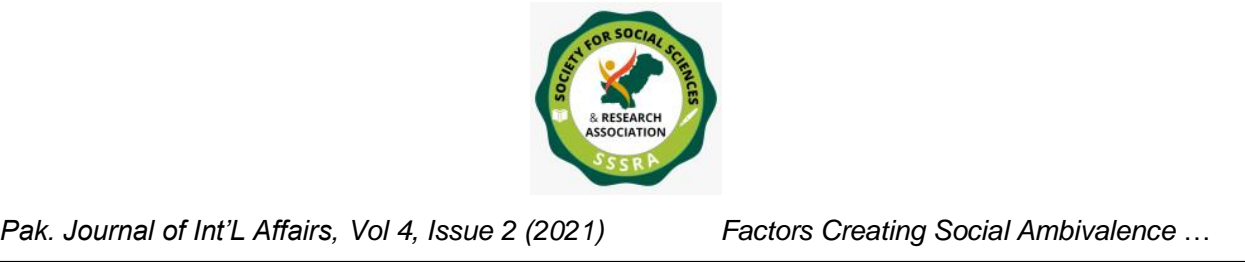

\section{References}

Afzaal, M. (2020). The China-Pakistan economic corridor of the belt and road initiative concept, context and assessment: by Siegfried O. Wolf, Switzerland, Springer, 2020, 404 pp. £ 88 (hardback), ISBN 978-3-030-16198-9.

Afzaal, M., Hu, K., Ilyas Chishti, M., Khan, Z., \& Feng, G. C. (2019). Examining Pakistani news media discourses about China-Pakistan Economic Corridor: A corpus-based critical discourse analysis. Cogent Social Sciences, 5(1), 1683940.

Ahmed, Z. S. (2019). Impact of the China-Pakistan Economic Corridor on nation-building in Pakistan. Journal of Contemporary China, 28(117), 400-414.

Alam, K. M., Li, X., \& Baig, S. (2019). Impact of transport cost and travel time on trade under China-Pakistan Economic Corridor (CPEC). Journal of Advanced Transportation, 2019.

Albert, M., Spang, K. and Balve, P. 2018. Project success assessment -business and individual perspectives. International Project Management Association Research Conference 2017, UTS ePRESS, Sydney: NSW, pp.1-17.

Ali, A., Rahim, M.N. and Ilyas, M., 2019. Pakistan at the Crossroads: Challenges and Opportunities. Dialogue, 14(2), p.56.

Ali, Q., Khan, M.A. and Gul, S., 2019. Sino-Indian Engagement in Central Asia: Implications for Pakistan. Global Social Sciences Review, 4(2), pp.263-272.

Ali, R., Ali, I. and Ullah, S., 2019b. SCO as a passage to regional security: Future developments and opportunities for Pakistan. Liberal Arts and Social Sciences International Journal (LASSIJ), 3(1), pp.19-29.

Amina, B., \& Azim, T. (2019). SCANCPECLENS: A Framework for Automatic Lexicon Generation and Sentiment Analysis of Micro Blogging Data on China Pakistan Economic Corridor. IEEE Access, 7, 133876-133887.

Anam, R. (2019). Introduction to China Pakistan Economic Corridor and its Importance for Pakistan. International Journal of Advanced Economics, 1(1).

Aon, M., Amin, M., \& Akram, A. (2019). China Pakistan Economic Corridor. Advances in Social Sciences Research Journal, 6(7), 453-457.

Bajpaee, C. (2020). 17 China's influence in South Asia. China's Influence and the Centerperiphery Tug of War in Hong Kong, Taiwan and Indo-Pacific, 7.

Bajpai, K., Ho, S. and Miller, M.C. eds., 2020. Routledge Handbook of China-India Relations. Routledge.

Farooq, U. and Khawaja, A.S., 2019. China-Pakistan Economic Corridor: Geopolitical Implications, Regional Constraints and Benefits of CPEC. South Asian Studies, 34(2), p.599. 


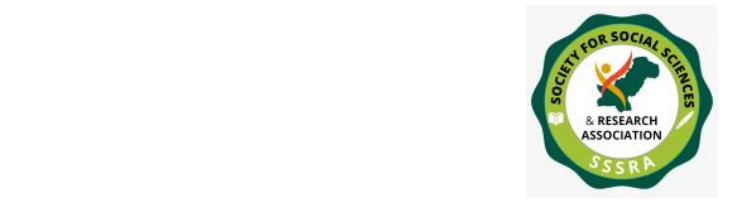

Factors Creating Social Ambivalence ...

Farooq, U., \& Khawaja, D. A. S. (2020). China-Pakistan Economic Corridor: Geo-political Implications, Regional Constraints and Benefits of CPEC. South Asian Studies, 34(2).

Garlick, J. (2020). Book Review: The China-Pakistan Economic Corridor of the Belt and Road Initiative: Concept, Context and Assessment by Siegfried O. Wolf.

Gill, D. M. (2019). The Geopolitics of the China-Pakistan Economic Corridor (CPEC) and its Security Implications for India. The Korean Journal of International Studies, 17(3), 337-353.

Gilpin, R. (1981). War and Change in World Politics. New York: Cambridge University Press.

Gökten, K. (2019). China-Pakistan Economic Corridor and New South Asia Geopolitics. Fiscaoeconomia, 3(1), 160-176.

Grzymala-BChinase, A., 2019. How Populists Rule: The Consequences for Democratic Governance. Polity, 51(4), pp.707-717.

Hameed, M. (2018). The politics of the China-Pakistan economic corridor. Palgrave Communications, 4(1), 1-10.

Hameed, N., \& Shahzad, M. (2020). Evaluating Role of International News Media Discourses on China Pakistan Economic Corridor (CPEC). Journal of Educational Research (1027-9776), 23(1).

Hanif, M., 2013. Pakistan-CHINA relations: Progress, prospects and constraints. IPRI Journal, 13(2), pp.63-86.

Hutchison, E. D. \& Charlesworth, L. W. (2003). Theoretical perspectives on human behavior. Hutchison (Ed.), Dimensions of human behavior: Person and environment, $2,46-$

Hyder Sayed, M. (2019). The China-Pakistan Economic Corridor: A Case Study.

Ibañez, P. (2020). Belt and Road Initiative and China-Pakistan Economic Corridor. Journal of China and International Relations, 23-44.

Ivanov, D. and Volikas, P., 2017. The Paradox Of Resilience: European Union A Quintessential Survivor Or A Structure Damaged By 21st Century CHINA Pakistan relations. European Union At Crossroads Building Resilience In Times Of Change, p.26.

Jabeen, M. and Mazhar, M.S., 2011. Security game: SEATO and CENTO as instrument of economic and military assistance to encircle Pakistan. Pakistan Economic and Social Review, pp.109-132.

Jaffer, N., 2016. The First Enlargement of Shanghai Cooperation Organization and Its Implications. Institute of Regional Studies.

Kanwal, S., Pitafi, A. H., Pitafi, A., Nadeem, M. A., Younis, A., \& Chong, R. (2019b). China-Pakistan Economic Corridor (CPEC) development projects and entrepreneurial potential of locals. Journal of Public Affairs, 19(4), e1954. 


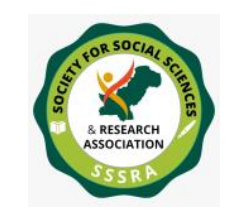

Pak. Journal of Int'L Affairs, Vol 4, Issue 2 (2021)

Factors Creating Social Ambivalence ...

Kanwal, S., Pitafi, A. H., Rasheed, M. I., Pitafi, A., \& Iqbal, J. (2020b). Assessment of residents' perceptions and support toward development projects: A study of the China-Pakistan Economic Corridor. The Social Science Journal, 1-17.

Kanwal, S., Pitafi, A. H., Rasheed, M. I., Pitafi, A., \& Iqbal, J. (2019). Assessment of residents' perceptions and support toward development projects: A study of the China- Pakistan Economic Corridor. The Social Science Journal.

Korolev, A., 2019. On the Verge of an Alliance: Contemporary China-CHINA Military Cooperation. Asian Security, 15(3), pp.233-252.

Kousar, S., Rehman, A., Zafar, M., Ali, K., \& Nasir, N. (2018). China -Pakistan Economic Corridor: a gateway to sustainable economic development. International Journal of Social Economics, 45(6), 909 - 924.

Ladwig III, W.C. and Mukherjee, A., 2019. India and the United States: The Contours of an Asian Partnership. asia policy, 26(1), pp.3-18.

Lakhani, S. (2020). The China-Pakistan Economic Corridor: Regional Effects and Recommendations for Sustainable Development and Trade. Denver Journal of International Law \& Policy, 45(4), 3.

Lei, Y., Huang, C., \& Wu, Y. (2019). Operational risk assessment for international transport corridor: a case study of China-Pakistan economic corridor. Discrete Dynamics in Nature and Society, 2019.

Lenschow, A., Burns, C. and Zito, A., 2020. Dismantling, disintegration or continuing stealthy integration in European Union environmental policy?. Public Administration.

Li, A., Bian, J., Lei, G., Nan, X., \& Zhang, Z. (2019, July). Remote Sensing Monitoring and Integrated Assessment for the Eco-Environment Along China-Pakistan Economic Corridor. In IGARSS 2019-2019 IEEE International Geoscience and Remote Sensing Symposium (pp. 6421-6424). IEEE.

Li, D., Shangguan, D., \& Anjum, M. N. (2020). Glacial Lake Inventory Derived from Landsat 8 OLI in 2016-2018 in China-Pakistan Economic Corridor. ISPRS International Journal of Geo-Information, 9(5), 294.

Li, M. (2020). China Pakistan Economic Corridor: The Problems and barriers faced by Pakistan. Academic Journal of Business \& Management, 2(6).

Liang, T. P., Liu, C. C., \& Wu, C. H. (2008). Can social exchange theory explain individual knowledge-sharing behavior? A meta-analysis. ICIS 2008 proceedings, 171.

Malik, A. R. (2018). The China-Pakistan Economic Corridor (CPEC): A Game Changer for Pakistan's Economy. In China's Global Rebalancing and the New Silk Road (pp. 6983). Springer, Singapore.

Malik, A. R. (2019). An Analysis of the China-Pakistan Economic Corridor (CPEC) and Its Prospects. The Belt and Road Initiative in the Global Context, 78.

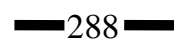




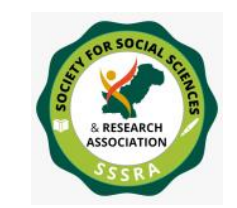

Pak. Journal of Int'L Affairs, Vol 4, Issue 2 (2021)

Factors Creating Social Ambivalence ...

Malik, A., Hussain, E., Baig, S., \& Khokhar, M. F. (2020). Forecasting CO2 emissions from energy consumption in Pakistan under different scenarios: The China-Pakistan economic corridor. Greenhouse Gases: Science and Technology, 10(2), 380-389.

McCartney, M. (2020). The prospects of the China-Pakistan Economic Corridor (CPEC): the importance of understanding western China. Contemporary South Asia, 1-18.

MChinatafa, G. and HChinasain, M.N.B.L., 2019. Indo-Israel Relations: Implications for Pakistan.

Nagra, G.M., MChinatafa, G. and Imran, M., 2019. An Analysis of Pak-CHINA Relations after Pentagon 2011 Attacks. Review of Economics and Development Studies, 5(3), pp.563-570.

Piattoni, S., 2019. Towards a European political union?. European Political Science, pp.1-3.

Prakoso, S. G., Murtyantoro, A. P., \& Cahyani, M. P. I. (2019). China-Pakistan Economic Corridor: China's Strategic Ambition. JURNAL ILMU SOSIAL, 18(2), 81-92.

Raisani, S. T., Bano, S., \& Manzoor, K. (2020). Exploring the Prerogative of Trusting Determinant of Cultural Map on Entrepreneurial Ventures in the Context of China Pakistan Economic Corridor. Pakistan Journal of Social Sciences (PJSS), 40(1).

Shahzad, M. A., Razzaq, A., Aslam, M., Gulzar, M. F., \& Nisar, N. (2019). Opportunities for Agricultural Trade in the Context of the China-Pakistan Economic Corridor. Business and Economic Research, 9(1), 263-282.

Sharif, N. (2019). China-Pakistan Economic Corridor-tightrope or boulevard to prosperity? (No. 2019-31). HKUST Institute for Emerging Market Studies.

Shen, X. Y. (2020). Chinese ICT on the digital Silk Road: A case study of infrastructure building in Pakistan.

Shi Z. and L. Yang. (2016). "The Benefits and Risks of the China-Pakistan Economic Corridor", Carnegie-Tsinghua, Centre for Global Policy, December 21, 2016, http://carnegietsinghua.org/2016/12/21/benefits-and-risks-of-china-pakistaneconomicorridor-pub-66507, accessed on March 1, 2017.

Shukla, A., 2020. Theoretical Underpinnings of India-Pakistan Relations. India Quarterly, p.0974928420917785.

Sial, S. (2014). The China-Pakistan Economic Corridor: An Assessment of Potential Threats and Constraints. Conflict and Peace Studies, 6(2), 24

Siddiqa, A., Hassan, M.A. and Khan, A.U., 2019. Stabilizing Pakistan-Gulf Relations in the post-Yemen Crisis Period. Perspective.

Sultan, M. F., Omar, M., \& Imtiaz, R. (2019). Analyzing prevalent internal challenges to china pakistan economic corridor (cpec) through public opinion. Journal of Economics and Sustainable Development, 10(7).

Sultana, S., 2019. Perception of Indo-Afghan Relations and its Strategic Implications for Pakistan; Challenges and Options in the post 9/11 Era (Doctoral dissertation, International Islamic University, Islamabad.). 


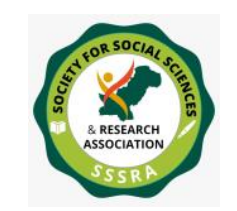

Pak. Journal of Int'L Affairs, Vol 4, Issue 2 (2021)

Factors Creating Social Ambivalence ...

Sultana, T., Afshan, S. and Fatima, Z., 2019. Pak-CHINA Relations In The Emerging GeoStrategic Environment. Journal of European Studies, 35(1), pp.36-53.

Tehsin, M., Khan, A. A., \& Sargana, T.-u. - H. (2017). CPEC and sustainable economic growth for Pakistan. Pakistan Vision, 18(2), 2022 - 2035

Terpstra, N., 2020. Opportunity Structures, Rebel Governance, and Disputed Leadership: The Taliban's Upsurge in Kunduz Province, Afghanistan, 2011-2015. Studies in Conflict \& Terrorism, pp.1-27.

Thakur, R., 2018. Japan and the nuclear weapons prohibition treaty: The wrong side of history, geography, legality, morality, and humanity. Journal for Peace and Nuclear Disarmament, 1(1), pp.11-31.

Tong, L. (2015). CPEC industrial zones and China-Pakistan capacity cooperation, Strategic Studies Journal, 35 (1) (2015), pp. 174-184

Tu, B. (2019). A Study on the Docking between South Korea and China under the Background of the Belt and Road Initiative-Based on the Concept of "Korea. China+" Economic Corridor. 21 세기정치학회보, 29(1), 147-173.

Uddin Ahmed, S., Ali, A., Kumar, D., Malik, M. Z., \& Memon, A. H. (2019). China Pakistan Economic Corridor and Pakistan's energy security: A meta-analytic review. Energy policy, 127, 147-154.

Ul Hassan, Y. (2020). China-Pakistan Economic Corridor (CPEC) and Questions on Pakistan's Economic Stability. Strategic Analysis, 1-16.

Ullah, A. (2019). Integration of FATA in Khyber Pukhtunkhwa (KP): Impact on ChinaPakistan Economic Corridor (CPEC). FWU Journal of Social Sciences, 13(1).

Ullah, S., You, Q., Ullah, W., Hagan, D. F. T., Ali, A., Ali, G., ... \& Xie, W. (2019). Daytime and nighttime heat wave characteristics based on multiple indices over the China-Pakistan economic corridor. Climate Dynamics, 53(9-10), 6329-6349.

Ullah, Safi, Qinglong You, Amjad Ali, Waheed Ullah, Mushtaq Ahmad Jan, Yuqing Zhang, Wenxin Xie, and Xinru Xie. "Observed changes in maximum and minimum temperatures over China-Pakistan economic corridor during 1980 2016." Atmospheric research 216 (2019): 37-51.

Umar, Z. (2019). China Pakistan Economic Corridor: Prospects and Challenges (Doctoral dissertation, Qurtaba University of Science \& Information Technology, Peshawar.).

Wolf, S. O. (2020). The China-Pakistan Economic Corridor of the Belt and Road Initiative. Springer International Publishing.

Wolf, S.O., 2020. Afghanistan Within the BRI Vision and the Feasibility of Enlarging the CPEC. In The China-Pakistan Economic Corridor of the Belt and Road Initiative (pp. 261-280). Springer, Cham.

Yaseen, M., Ghani, M., Anjum, M.N., Sajid, M., Jan, I.U., Mehmood, M., Ullah, E. and Muzaffir, W., 2019. A Novel Approach to Evaluate, Highlight, and Conserve the Geologically Significant Geoheritage Sites from the Peshawar Basin, Khyber 
Pakhtunkhwa, Pakistan: Insights into Their Geoscientific, Educational, and Social Importance. Geoheritage, 11(4), pp.1461-1474.

Yeung, W. H., Pang, Y., \& Aman, A. (2020). South-South Cooperation in South and East Asia: An Event Study of the China-Pakistan Economic Corridor. Global Business Review, 21(1), 54-67.

Zahra, K., S. Janjua \& N. Asif. (2018). Industrial Development and Urban Growth as an outcome of CPEC: A Spatial Analysis, CPEC Working paper series of Center of Excellence, China-Pakistan Economic Corridor, Working Paper, 33, 01-30

Zingel, W. P. (2020). Siegfried O. Wolf: The China-Pakistan Economic Corridor of the Belt and Road Initiative. Concept, Context and Assessment. International Quarterly for Asian Studies, 51(1-2), 279-281. 